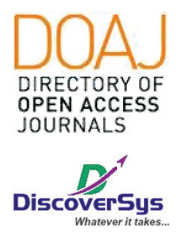

Published by DiscoverSys

\section{Peningkatan kadar Mean Platelet Volume- Lymphocyte Ratio (MPVLR) terhadap resiko diabetik nefropati pada pasien dengan diabetes melitus tipe II (DM-2) di RSUP Sanglah, Bali, Indonesia}

\author{
Budi Ratna Aryani, ${ }^{1 *}$ I Made Yoga Prabawa, ${ }^{1}$ Made Ratna Saraswati ${ }^{2}$
}

\title{
ABSTRACT
}

Background: Diabetic Nephropathy (DN) is Diabetes Mellitus's microvascular complication with albuminuria and decrease glomerular filtration rate. DN pathogenesis is related with inflammatory process induced by chronic hyperglycaemia. Mean platelet volume (MPV) and platelet-lymphocyte ratio (PLR) are potential for reviewing systemic inflammation. The combination of MPV and PLR index into MPVLR shows significant results in prognostic patients with diabetes mellitus and acute myocardial infarction and predicted DN. This study aims to determine the MPVLR index of DN risk in type II diabetes mellitus patients at Sanglah Hospital, Denpasar.

Method: Cross-sectional study of $50 \mathrm{DM}-2$ patients at Sanglah Hospital in 2016. The data is secondary data from the medical records of DM-2 patients according the inclusion and exclusion criteria with purposive sampling technique. Diabetic nephropathy is diagnose based on diagnostic criteria. Complete blood count (CBC) using the CELL-DYN Ruby System. MPVLR is an absolute comparison of the calculation of MPV and total lymphocytes. T-test and MannWhitney Test to assess differences mean of data. The MPVLR index for diabetic nephropathy was assessed by Receiver Operating Curve (ROC) and Area Under the Curve (AUC). $p<0.05$ is statistically significant.

Results: 50 data were grouped into nephropathy and without nephropathy groups. Men is dominant in both groups ( $p>0.05$ ). The MPVLR ratio was statistically significantly higher in the nephropathy group (5.11 $\pm 2.20 ; P=0.004)$. The MPVLR index cut point value was 3.835 with a sensitivity value of $73.7 \%$ and specificity of $71 \%$. Conclusion: MPVLR can use as independent predictor of diabetic nephropathy in diabetic patients.

Keywords: Diabetes Mellitus type II, Nephropathy Diabetic, MPVLR

Cite This Article: Aryani, B.R., Prabawa, I.M.Y., Saraswati, M.R. 2020. Peningkatan kadar Mean Platelet Volume-Lymphocyte Ratio (MPVLR) terhadap resiko diabetik nefropati pada pasien dengan diabetes melitus tipe II (DM-2) di RSUP Sanglah, Bali, Indonesia. Intisari Sains Medis 11(1): 328-332. D0I: 10.15562/ism.v11i1.632

\section{ABSTRAK}

Latar Belakang: Diabetik Nefropati (DN) merupakan komplikasi mikrovaskular Diabetes Melitus dengan albuminuria dan penurunan estimasi laju filtrasi glomerulus. Patogenesis DN berkaitan dengan proses inflamasi terinduksi hiperglikemia kronis. Indeks rerata volume trombosit (MPV) dan rasio trombosit-limfosit (PLR) potensial untuk meninjau inflamasi sistemik. Gabungan indeks MPV dan PLR menjadi MPVLR menunjukan hasil yang signifikan dalam diagnostik prognostik pada pasien diabetes melitus dan infarksi miokardial akut serta menjadi prediktor DN. Penelitian ini bertujuan untuk mengetahui indeks MPVLR terhadap risiko DN pada pasien diabetes melitus tipe II di RSUP Sanglah, Denpasar.

Metode: Studi potong lintang (cross-sectional) terhadap 50 pasien DM-2 di RSUP Sanglah tahun 2016. Data penelitian adalah data sekunder dari rekam medis pasien DM-2 yang memenuhi kriteria Inklusi dan Eksklusi dengan teknik purposive sampling. Diabetik nefropati ditegakkan berdasarkan kriteria diagnosis. Pemeriksaan darah lengkap (DL) menggunakan CELL-DYN Ruby System. Rasio MPV terhadap limfosit (MPVLR) adalah perbandingan absolut dari perhitungan MPV dan limfosit total. Uji-t dan Uji Mann-Whitney untuk menilai perbedaan antara rata-rata data dua kelompok. Indeks MPVLR terhadap diabetic nefropati dinilai dengan Receiver Operating Curve (ROC) dan Area Under the Curve (AUC). Nilai $p<0,05$ bermakna secara statistik.

Hasil: 50 data dikelompokkan menjadi kelompok dengan nefropati dan tanpa nefropati. Jenis kelami laki-laki dominan di kedua keompok tersebut $(p>0,05)$. Rasio MPVLR secara statistik bermakna lebih tinggi pada kelompok dengan nefropati $(5,11 \pm 2,20 ; P=0,004)$. Nilai titik potong indeks MPVLR sebesar 3,835 dengan nilai sensitifitas sebesar 73,7\% dan spesifisitas $71 \%$.

Simpulan: MPVLR dapat sebagai prediktor kuat dan independen diabetik nefropati pada pasien diabetes.
Dokter Umum, Alumni Fakultas

Kedokteran, Universitas Udayana,

Bali, Indonesia

budiratnaaryani1992@gmail.com

Diterima: 29-09-2019

Disetujui: 17-03-2020

Diterbitkan: 01-04-2020
Kata kunci: Diabetes Melitus tipe Il, Diabetik Nefropati, MPVLR.

Cite Pasal Ini: Aryani, B.R., Prabawa, I.M.Y., Saraswati, M.R. 2020. Peningkatan kadar Mean Platelet Volume-Lymphocyte Ratio (MPVLR) terhadap resiko diabetik nefropati pada pasien dengan diabetes melitus tipe II (DM-2) di RSUP Sanglah, Bali, Indonesia. Intisari Sains Medis 11(1): $328-332$. D0l: 10.15562/ism.v11i1.632 


\section{LATAR BELAKANG}

Diabetes mellitus (DM) adalah penyakit sistemik yang ditandai dengan ketidakmampuan tubuh untuk memproduksi atau merespons secara efektif hormon pengatur glukosa, insulin. ${ }^{1}$ Terdapat dua tipe DM yaitu DM tipe 1 dan DM tipe 2. DM tipe 1 merupakan hasil dari penghancuran $\beta$-sel pankreas secara idiopatik autoimun, sementara terjadinya resistensi insulin perifer yang luas akan disebut sebagai DM tipe 2. ${ }^{1} \mathrm{DM}$ akan ditandai dengan kondisi hiperglikemia yang dimana mengganggu homeostasis hemodinamik dan metabolik, sedangkan sifat kronis dari ketidakseimbangan lingkungan mikro tersebut mendorong perkembangan abnormalitas seluler yang difus. Akibatnya, banyak pasien mengalami komplikasi serius, yang paling parah adalah disfungsi vaskular yang luas. ${ }^{2}$ Mengingat bahwa ginjal sangat sensitif terhadap perubahan hemodinamik dan metabolisme, sehingga ginjal merupakan target yang rentan dalam diabetes mellitus.

Diabetik Nefropati (DN) merupakan komplikasi mikrovaskular dari DM. DN ditandai dengan albuminuria (albumin urin terhadap kreatinin rasio $\geq 30 \mathrm{mg} / \mathrm{g}$ ) dan berujung dengan penurunan dalam estimasi laju filtrasi glomerulus (eGFR $<60 \mathrm{ml} /$ menit/1,73 $\mathrm{m}^{2}$ ). ${ }^{3}$ Patogenesis dari DN berkaitan dengan adanya proses inflamasi, salah satunya melalui jalur reaktif oksigen spesies yang memicu stres oksidatif. Kondisi hiperglikemia pada DM diketahui menyebabkan glikasi protein non-enzimatik dan produk akhir seperti basa Schiff dan produk Amadori, yang berujung pada peningkatan produksi spesies oksigen reaktif (ROS). ${ }^{4}$ Adanya stres oksidatif akan memicu pelepasan berbagai sitokin pro-inflamasi yang memiliki dampak negatif pada penghalang permeabilitas protein dari glomerulus sehingga menginduksi perubahan faktor hemodinamik sel ginjal seperti penebalan membran basal glomerulus, ekspansi sel mesangial ginjal (sel ekstra-glomerulus atau intra-glomerulus) dan hiperplasia matriks ekstraseluler., ${ }^{5,6}$

Studi terkini menunjukan bahwa indeks terkait sel darah, termasuk rerata volume trombosit (MPV) dan rasio trombosit-limfosit (PLR) adalah biomarker baru yang potensial dari respons inflamasi sistemik. ${ }^{7,8}$ MPV adalah parameter yang mencerminkan ukuran rata-rata trombosit dan MPV tinggi menunjukkan bahwa trombosit memiliki ukuran besar. Trombosit yang lebih besar biasanya memiliki aktivitas metabolik dan enzimatik yang tinggi dan melepaskan lebih banyak tromboxan-A2, b-tromboglobulin, dan molekul adhesi dibandingkan dengan ukuran yang lebih kecil. ${ }^{910}$ Telah dilaporkan bahwa MPV yang tinggi mungkin menjadi risiko untuk beberapa kondisi pembuluh darah, termasuk penyakit arteri perifer, penyakit arteri koroner, infark miokard dan iskemia serebral. ${ }^{11}$ Selain itu, banyak penelitian telah menunjukkan bahwa PLR adalah biomarker inflamasi potensial pada tumor dan penyakit kardiovaskular. ${ }^{12,13}$ PLR berdasarkan studi terbaru pada pasien diabetes melitus menunjukan bahwa level PLR berkorelasi positif yang signifikan dengan albuminuria. ${ }^{14}$ Studi terbaru yang menggabungkan indeks aktivitas platelet pada MPV dan indeks interaksi antara platelet dan inflamasi sistemik pada PLR menjadi MPVLR menunjukan hasil yang signifikan dalam indeks diagnostik prognostik pada pasien diabetes melitus dan infarksi miokardial akut serta menjadi prediktor DN pada pasien diabetes melitus. ${ }^{15,16}$ Sehingga, penelitian ini bertujuan untuk mengetahui indeks MPVLR terhadap risiko DN pada pasien diabetes melitus di RSUP Sanglah, Denpasar.

\section{METODE}

Studi potong lintang (cross-sectional) dilakukan terhadap 50 pasien dengan riwayat DM-2 di Poliklinik Penyakit Dalam, Bagian Pusat Diabetes, RSUP Sanglah tahun 2016. Seluruh data pasien berupa data sekunder yang terdapat pada rekam medis pasien DM-2 yang memenuhi kriteria Inklusi dan Eksklusi. Teknik pengambilan sampel data sekunder yang dilakukan pada penelitian ini menggunakan non-probability sampling melalui purposive sampling technique. Adapun kriteria inklusi yang dipergunakan pada pasien ini meliputi: 1) Riwayat DM-2 sejak 5 tahun terakhir; 2) Penggunaan rutin pengobatan baik berupa obat hipoglikemik oral (OHO) ataupun suntikan insulin secara prandial maupun basal; 3) tidak terdapat komplikasi akut DM-2 sebelumnya baik berupa DKA, HHS, atau hipoglikemia sebelumnya; dan 4) memiliki data laboratorium yang lengkap saat pertama kali didiagnosis dengan DM-2 dan diperiksa pada tahun 2016 dimana mencakup data pemeriksaan darah lengkap, gula darah sewaktu, usia, dan jenis kelamin.

Data responden penelitian yang terkumpul terbagi 2 atas pasien dengan DM-2 tanpa diabetik nefropati dan dengan diabetik nefropati. Penegakan diagnosis diabetik nefropati dicirikan dengan sindroma yang terdapat pada pasien dengan riwayat DM-2 dimana mencakup: 1) Albuminuria persisten $(>300 \mathrm{mg} / \mathrm{hari}$ atau $>200 \mu \mathrm{g} / \mathrm{menit}$ ) yang dikonfirmasi dengan minimal 2 kejadian dalam rentang waktu 3-6 bulan; 2) penurunan nilai GFR ginjal secara progresif; 3) peningkatan tekanan darah ( $\geq 140 \mathrm{mmHg}$ untuk sistolik dan $\geq 90 \mathrm{mmHg}$ untuk diastolik); dan/atau 4) terdapat keberadaan 
glomerulosklerosis melalui pemeriksaan patologi anatomi. Pemeriksaan darah lengkap (DL)/complete blood count (CBC) yang dilakukan di RSUP Sanglah dan tercatat pada rekam medis menggunakan CELL-DYN Ruby System sebagai hematology analyser. Parameter yang dinilai mencakup sel darah merah (RBC), hemoglobin ( $\mathrm{Hb}$ ), nilai absolut Platelet, nilai absolut Mean Platelet Volume (MPV), Red Cell Distribution Width (RDW), nilai absolut limfosit, dan kadar HbA1C. Rasio MPV terhadap limfosit (MPVPLR) didefinisikan sebagai perbandingan absolut dari perhitungan MPV dan limfosit total.

Data yang diperoleh kemudian dianalisis menggunakan SPSS versi 17 untuk Windows. Distribusi data ditentukan menggunakan analisis KolmogorovSmirnov. Apabila data berdistribusi normal, maka variabel data numerik ditampilkan dalam bentuk rerata \pm simpang baku (SB). Sedangkan data yang tidak berdistribusi normal ditampilkan dalam bentuk nilai median (minimum-maksimum). Uji Mann-Whitney digunakan untuk mengevaluasi perbedaan antara median data yang terdistribusi tidak normal dan Uji-t digunakan untuk menilai perbedaan antara rata-rata data terdistribusi normal. Uji korelasi Pearson dilakukan untuk menentukan kuat dan arah korelasi antara resiko diabetik nefropati dengan nilai MPVLR. Nilai titik potong (cut-off value) untuk menetukan nilai diskriminatif MPVLR terhadap diabetik nefropati dilakukan dengan Receiver Operating Curve (ROC) dan dinilai menggunakan penilaian pada Area Under the Curve (AUC) untuk menentukan nilai sensitivitas dan spesifisitasnya. Nilai $\mathrm{p}<0,05$ dianggap bermakna secara statistic. Data yang diperoleh telah mendapat persetujuan etik dari Komisi Etik Fakultas Kedokteran Universitas Udayana tahun 2016.

\section{HASIL}

Hasil penelitian ini menunjukkan bahwa terdapat 50 data rekam medis responden yang memenuhi kriteria inklusi dan eksklusi. Sebagian besar responden berjenis kelamin laki-laki pada kelompok DM Nefropati $(57,9 \%)$ maupun pada kelompok DM Non-Nefropati $(54,8 \%)$ meskipun secara statistik tidak bermakna $(\mathrm{P}>0,05)$ (Tabel 1$)$. Tidak terdapat perbedaan bermakna dari segi usia, nilai RDW, RBC, hemoglobin, limfosit, MPV, HbA1C, maupun platelet antara kedua kelompok penelitian $(\mathrm{P}>0,05)$ (Tabel 1). Akan tetapi, terdapat perbedaan hasil pada pemeriksaan MPVLR dimana rasio MPVLR secara statistik bermakna lebih tinggi pada kelompok dengan DM Nefropati $(5,11 \pm 2,20$; $\mathrm{P}=0,004)$ dibandingkan dengan DM Non-Nefropati (Tabel 1).

Untuk menunjukkan apakah nilai rasio MPVLR dapat dipergunakan sebagai faktor prediktor maka uji menggunaka Receiver Operating Curve (ROC) dilakukan untuk menentukan nilai sensitivitas maupun spesifisitas serta nilai titik potong nya (cut-off value). Hasil penelitian menunjukkan bahwa nilai Area Under the Curve (AUC) pada MPVLR adalah sebesar 0,747 dimana secara statistik memiliki arti prediksi kuat secara bermakna $(\mathrm{P}=0,004)$. Nilai titik potong yang dapat dipergunakan pada penelitian ini adalah 3,835 dengan

Tabel 1 Karakteristik responden berdasarkan demografis dan pemeriksaan laboratorium antara kelompok DM dengan Nefropati dan tanpa Nefropati

\begin{tabular}{|c|c|c|c|}
\hline \multirow[b]{2}{*}{ Variabel } & \multicolumn{2}{|c|}{ Responden Penelitian $(\mathrm{N}=50)$} & \multirow[b]{2}{*}{$\mathbf{P}$} \\
\hline & DM Nefropati (N=19) & DM Non-Nefropati ( $\mathrm{N}=31$ ) & \\
\hline \multicolumn{4}{|l|}{ Jenis kelamin $(\mathrm{N}, \%)$} \\
\hline Laki-Laki & $11(57,9)$ & $17(54,8)$ & $0,534^{\mathrm{a}}$ \\
\hline Perempuan & $8(42,1)$ & $14(45,2)$ & \\
\hline Usia (Tahun) & $48,52 \pm 12,61$ & $47,29 \pm 11,51$ & $0,724^{\mathrm{b}}$ \\
\hline RDW (\%) & $16,25(10,91-24,29)$ & $17,03(13,72-260,2)$ & $0,079^{c}$ \\
\hline $\mathrm{RBC}(1 \times 106 / \mathrm{mm} 3)$ & $4,95 \pm 2,60$ & $4,62 \pm 0,97$ & $0,520^{\mathrm{b}}$ \\
\hline Hemoglobin $(\mathrm{g} / \mathrm{dL})$ & $15,72 \pm 6,96$ & $15,11 \pm 3,98$ & $0,692^{\mathrm{b}}$ \\
\hline MPV (fl) & $8,06(7,4-109,9)$ & $7,54(4,23-7,88)$ & $0,076^{c}$ \\
\hline Limfosit $(1 \times 103 / \mu \mathrm{L})$ & $2,11(1,08-11,34)$ & $2,42(0,87-4,71)$ & $0,675^{c}$ \\
\hline Platelet $(1 \times 103 / \mu \mathrm{L})$ & $230,8(134,1-468)$ & $280,9(112,4-792,1)$ & $0,139^{c}$ \\
\hline $\operatorname{HbA1C}(\%)$ & $6,35 \pm 0,63$ & $6,10 \pm 0,56$ & $0,069^{\mathrm{b}}$ \\
\hline MPVLR (\%) & $5,11 \pm 2,20$ & $3,29 \pm 1,98$ & $0,004^{b *}$ \\
\hline
\end{tabular}

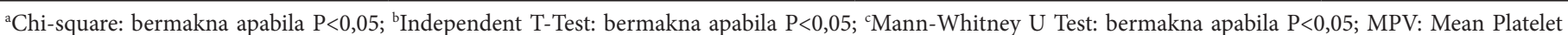
Volume; MPVLR: Mean Platelet Volume to Lymphocyte Ratio; RDW: Red Cell Distribution Width; RBC: Red Blood Cells; ${ }^{\star}$ : Bermakna secara statistik. 


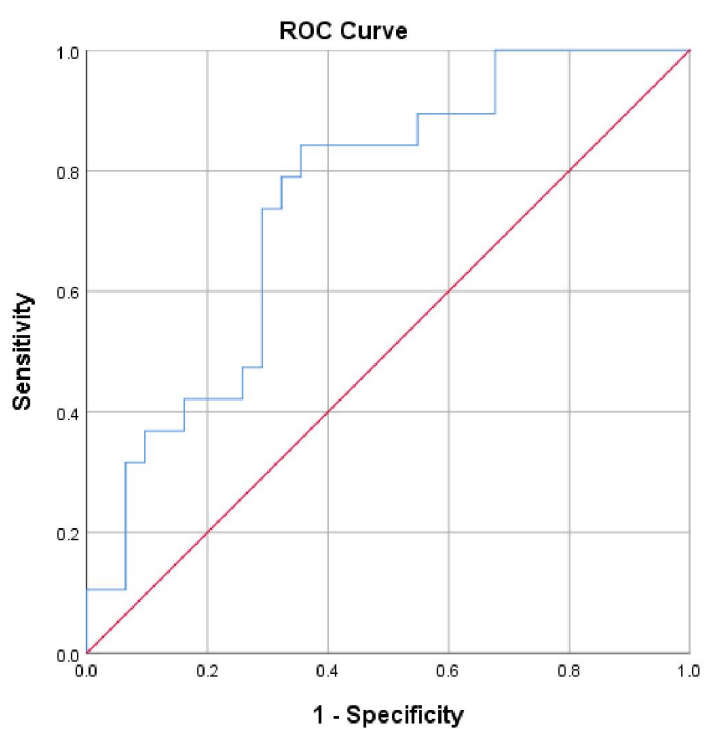

Gambar 1 Hasil analisis ROC pada MPVLR terhadap resiko DM Nefropati

nilai sensitifitas sebesar $73,7 \%$ dan spesifisitas $71 \%$ (Gambar 1).

\section{DISKUSI}

Pada penelitian ini menunjukan bahwa MPVLR bermakna secara statistik pada pasien diabetes dengan diabetes nefropati dan memiliki nilai prediktor sensitifitas dan spesifitas diatas $70 \%$. Hal ini sejalan dengan hasil peneltian Kocak, dkk., yang membandingkan rerata MPVLR pada pasien dengan dan tanpa diabetes nefropati. Pada penelitian tersebut menunjukan MPVLR bermakna secara statistik pada diabetes nefropati serta lebih spesifik dan sensitif dari pada MPV dan PLR, dimana didapatkan sensitifitas sebesar $71,1 \%$ dan spesifitas $68 \%$. Sehingga pada penelitian ini hanya berfokus pada indeks MPVLR terhadap risiko diabetes nefropati pada pasien diabetes melitus.

Diabetes mellitus (DM) adalah penyakit sistemik kronis. Berbagai literatur telah menunjukan bahwa peradangan kronis terlibat dalam resistensi insulin dan pengembangan DM. ${ }^{17,18}$ Selain itu, akumulasi bukti telah memperlihatkan bahwa respons inflamasi juga memainkan peran kunci dalam pengembangan dan perkembangan DN. ${ }^{6}$ Telah diketahui bahwa respon infalamasi berkaitan dengan peran dari limfosit. ${ }^{19,20}$ PLR telah dilaporkan menunjukkan hiperaktif dari jalur inflamasi. Jumlah trombosit yang tinggi mencerminkan inflamasi yang mendasarinya, karena banyak mediator inflamasi merangsang proliferasi megakariosit dan menyebabkan trombositosis relatif. ${ }^{21}$ Namun, ukuran trombosit menunjukkan aktivitas trombosit lebih akurat daripada jumlah trombosit. Hal ini berkaitan dengan semakin besarnya ukuran trombosit maka semakin meningkat pula aktivitas metabolik dan enzimatik dan serta melepaskan lebih banyak tromboxan-A2, b-tromboglobulin, dan molekul adhesi. ${ }^{9,10}$ MPVLR, yang dihitung menggunakan MPV dan bukan jumlah trombosit dalam PLR, diklaim sebagai indeks aktivitas trombosit yang lebih relevan. ${ }^{22}$ Studi Hudzik, dkk., menunjukan bahwa kadar MPVLR yang meningkat pada subyek diabetes dengan ST elevasi infark miokard memiliki prognosis buruk baik jangka pendek maupun jangka panjang. ${ }^{15}$

\section{SIMPULAN}

MPVLR adalah indeks darah yang mudah untuk dihitung dan efisien serta dapat sebagai prediktor kuat dan independen diabetik nefropati pada pasien diabetes. Penulis menyarankan bahwa, indeks MPVLR dapat sebagai tambahan dalam tes standar diagnosis nefropati diabetik.

\section{KONFLIK KEPENTINGAN}

Penulis menyatakan tidak terdapat konflik kepentingan terkait publikasi dari penelitian ini.

\section{PENDANAAN}

Penelitian ini tidak mendapatkan bantuan dana hibah dari pemerintah maupun sektor swasta lainnya.

\section{ETIKA DALAM PENELITIAN}

Penelitian ini telah mendapatkan persetujuan dari Komite Etik Fakultas Kedokteran Universitas Udayana/RSUP Sanglah Denpasar.

\section{DAFTAR PUSTAKA}

1. American Diabetes Association Diagnosis and classification of diabetes mellitus. Diabetes Care. 2014;37:S81-S90. doi: $10.2337 / \mathrm{dc} 14-$ S081.

2. Forbes JM, Cooper ME. Mechanisms of diabetic complications. Physiol Rev. 2013;93:137-188. doi: 10.1152/ physrev.00045.2011.

3. Toth-Manikowski S, Atta MG. Diabetic kidney disease: pathophysiology and therapeutic targets. J Diabetes Res. 2015;2015:697010. doi: 10.1155/2015/697010.

4. Magee C, Grieve DJ, Watson CJ, Brazil DP. Diabetic Nephropathy: a Tangled Web to Unweave. Cardiovasc Drugs Ther. 2017;31(5-6):579-592. doi: 10.1007/ s10557-017-6755-9

5. Oguntibeju OO. Type 2 diabetes mellitus, oxidative stress and inflammation: examining the links. Int J Physiol Pathophysiol Pharmacol. 2019;11(3):45-63. Published 2019 Jun 15.

6. Liu J, Liu X, Li Y, Quan J, Wei S, An S et al. The association of neutrophil to lymphocyte ratio, mean platelet volume, and platelet distribution width with diabetic retinopathy and nephropathy: a meta-analysis. Bioscience Reports. 2018;38(3):BSR20180172. 
7. Qin BD, Ma N, Tang QQ, Wei TT, Yang M, Fu HT, Hu ZD, Liang Y, Yang ZX, Zhong RQ. Neutrophil to lymphocyte ratio (NLR) and platelet to lymphocyte ratio (PLR) were useful markers in assessment of inflammatory response and disease activity in SLE patients. Mod Rheumatol. 2016;26(3):372-376.

8. Şenel E, Acar B, Demir E. Mean platelet volume: a reliable marker of inflammation in recurrent apthous stomatitis and Behçet disease? Indian Dermatol Online J. 2017;8(6):468-470.

9. Kamath S, Blann AD, Lip GY. Platelet activation: assessment and quantification. Eur Heart J. 2001;22(17):1561-1571.

10. Chu SG, Becker RC, Berger PB, Bhatt DL, Eikelboom JW, Konkle B, Mohler ER, Reilly MP, Berger JS. Mean platelet volume as a predictor of cardiovascular risk: a systematic review and meta-analysis. J Thromb Haemost. 2010;8(1):148-156.

11. Bozlu G, Karpuz D, Hallioglu O, Unal S, Kuyucu N. Relationship between mean platelet volume-tolymphocyte ratio and coronary artery abnormalities in Kawasaki disease. Cardiol Young. 2018;28(6):832-836.

12. Gunduz S, Mutlu H, Tural D, Yıldız Ö, Uysal M, Coskun HS, Bozcuk H. Platelet to lymphocyte ratio as a new prognostic for patients with metastatic renal cell cancer. Asia Pac J Clin Oncol. 2015;11(4):288-292.

13. Luo WJ, Zhang WF. The relationship of blood cell-associated inflammatory indices and diabetic retinopathy: a Meta-analysis and systematic review. Int J Ophthalmol. 2019;12(2):312-323. Published 2019 Feb 18. doi: 10.18240/ijo.2019.02.20.

14. Akbas EM, Demirtas L, Ozcicek A, et al. Association of epicardial adipose tissue, neutrophil-to-lymphocyte ratio and platelet-to-lymphocyte ratio with diabetic nephropathy. Int J Clin Exp Med. 2014;7(7):1794-1801. Published 2014 Jul 15.

15. Hudzik B, Szkodziński J, Lekston A, Gierlotka M, Poloński L, Gąsior M. Mean platelet volume-to-lymphocyte ratio: a novel marker of poor short- and long-term prognosis in patients with diabetes mellitus and acute myocardial infarction. Journal of Diabetes and its Complications. 2016;30(6):1097-1102.
16. Zahid Kocak M, Aktas G, Erkus E, T Duman T, M Atak B, Savli H. Mean Platelet Volume to Lymphocyte Ratio as a Novel Marker for Diabetic Nephropathy. Journal of the College of Physicians and Surgeons Pakistan. 2018;28(11):844-847.

17. Shoelson SE, Lee J, Goldfine AB. Inflammation and insulin resistance [published correction appears in J Clin Invest. 2006 Aug;116(8):2308]. J Clin Invest. 2006;116(7):17931801. doi: $10.1172 /$ JCI29069.

18. Stringhini S, Batty GD, Bovet P, et al. Association of lifecourse socioeconomic status with chronic inflammation and type 2 diabetes risk: the Whitehall II prospective cohort study. PLoS Med. 2013;10(7):e1001479. doi: 10.1371/journal.pmed.1001479.

19. Le Tulzo Y, Pangault C, Gacouin A, Guilloux V, Tribut O, Amiot L, et al. Early circulating lymphocyte apoptosis in human septic shock is associated with poor outcome. Shock. 2002; 18:487-94.

20. Prabawa IPY, Bhargah A, Liwang F, Tandio DA, Tandio AL, Lestari AAW, et al. Pretreatment Neutrophilto-Lymphocyte ratio (NLR) and Platelet-to-Lymphocyte Ratio (PLR) as a Predictive Value of Hematological Markers in Cervical Cancer. Asian Pac J Cancer Prev. 2019;20(3):863-868

21. Oylumlu M, Yildiz A, Oylumlu M, Yüksel M, Polat N, Bilik MZ, et al. Platelet-to-lymphocyte ratio is a predictor of in-hospital mortality patients with acute coronary syndrome. Anatol J Cardiol. 2015; 15:277-83.

22. Kurtul A, Acikgoz SK. Usefulness of mean platelet volume-tolymphocyte ratio for predicting angiographic no-reflow and short-term prognosis after primary percutaneous coronary intervention in patients with ST-segment elevation myocardial infarction. Am J Cardiol. 2017; 120:534-41.

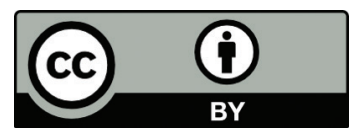

This work is licensed under a Creative Commons Attribution 